\title{
Microplate MPN-enumeration of monocyclic- and dicyclic-aromatic hydrocarbon degraders via substrate phase-partitioning
}

\author{
Anders R. Johnsen · Sidsel Henriksen
}

Published online: 19 May 2009

(C) Springer Science+Business Media B.V. 2009

\section{Erratum to: Biodegradation DOI 10.1007/s10532-008-9236-9}

Due to an unfortunate mistake a typographical error was introduced in Equation 1 of the above mentioned article. The correct Equation $\left(V_{\mathrm{o}}\right.$ should have read
$\left.V_{\text {pdms }}\right)$ is published below and should be treated as definitive by the reader:

$C_{\mathrm{w}}=\frac{m}{\left(1+\frac{V_{\mathrm{pdms}}}{V_{\mathrm{w}}} \times K_{\mathrm{pdms} / \mathrm{w}}\right) \times V_{\mathrm{w}}}$

The online version of the original article can be found under doi:10.1007/s10532-008-9236-9.

\footnotetext{
A. R. Johnsen $(\varangle) \cdot$ S. Henriksen

Department of Geochemistry, Geological Survey of Denmark and Greenland, Øster Voldgade 10, 1350 Copenhagen K, Denmark

e-mail: arj@geus.dk
} 